\title{
BROADCASTING AND TELEVISION SERVICES IN BRITAIN
}

\begin{abstract}
$\mathrm{A}^{\mathrm{P}}$ ART from its general interest, particularly its analysis of sound broadeasting and television over the past decade and its specific recommendations for future policy (see p. 927 of this issue), the report of the Pilkington Committee on Broadcasting* is of considerable interest to scientists, and its usefulness is enhanced by the appendage of the report of the Television Advisory Committee, 1960. Memoranda were submitted or evidence given to the Committee by a number of scientific bodies; for example, on science broadcasting, by the London Area Science Policy Committee of the Association of Scientific Workers, the British Association and the Royal Society, which were concerned with the third television programme and the Scientific Advisory Committee, as well as with science programmes. The Department of Scientific and Industrial Research submitted evidence on broadcasting of science and technology, recruitment and training of staff and the third television programme; the Institution of Electrical Engineers on research and on education and training of personnel; the National Research Development Corporation on the possibilities of band-width compression of television broadcast systems; the Nature Conservancy on natural history and conservation programmes; the Royal Horticultural Society on the need for planned instruction in horticulture; the Royal Society for the protection of birds on natural history programmes; the Scientific Film Association on educational broadcasting, treat. ment of medical programmes, effect of advertisements on scientific accuracy and objectivity; and the Television Society on a United Kingdom Com. munications Authority Co-ordinating Committee for research, line definition and colour, and educational broadcasting. Evidence on educational broadcasting or special aspects thereof was also submitted by numerous other bodies, including the Royal Society of Arts, the Universities Council for Adult Education, the University of Birmingham and the Workers' Educational Association.

While this list indicates well enough the range of scientific interest of the Report, the material of direct scientific interest is contained essentially in Part 4, which discusses the technical considerations; in Section 13 of Part 5, which discusses educational broadcasting; and in two short sections of Chapter 9 , which discuss some particular kinds of programme. Here, the forceful representations made by the Royal Society and the British Association are noted. They pointed to the compelling need to present to the public the significance of science, and argued for more programmes on the varied aspects of science and technology and on the applications of developing scientific thought and knowledge, suggesting the appointment of a scientist to the senior production staff of the B.B.C. to take charge of science programmes. The Pilkington Committee thought it was no part of its task to advocate that particular subjects should find a place, or larger place, in programmes, and merely suggested that the two broadcasting organizations should consider what steps, or what additional steps, should be taken to see that these specific needs are met.
\end{abstract}

* Report of the Committee on Broadcasting, 1960. (Cmnd. 1753.) Pp. xii +342. (London: H.M. Stationery Office, 1962.) 18s. net.
On educational broadcasting the Committee observes that broadcasting is concerned with educa. tion in four ways. First, through the broadcasts for schools and second through the educational broadcasts to those who have left school. Third, there are programmes which, though they do not aim specifically to teach their audiences, are clearly educative, such as those on medicine and science. Lastly, there is the generally educative effect of all programmes, of their diffused effect on knowledge, opinions and attitudes. Apart from schools' broadcasting, however, there is no sharp break between educational and generally educative programmes.

On schools' broadcasting three basic considerations were submitted to the Committee. The service must be so organized as to fit into the national educational system; the purpose of the broadcasts is to help, not to replace, the teacher; and the broadcasting authorities have a duty to include education in their programmes. From these considerations it follows that the broadcasting authorities, and not a central educational body, should provide the service; and because teaching is in the hands of teachers, the role of the broadcasting organizations is to be agents for the teachers. All the educational bodies which gave evidence appear to accept these consequences as an essential part of the policies governing broadcasting for schools. They are accepted by the B.B.C., but the Independent Television Authority has certain reservations about the first.

There was little criticism of the programmes, and the standard of schools' broadcasts on both sound and television is high, though the Committee also concludes that there is need for more programmes, especially on television. There was no criticism of either the B.B.C. or the Independent Television Authority for not providing programmes for universities or technical colleges now, even by those who thought that such programmes should be provided in the future. So far as they go-and in sound broadcast. ing they go a good way-the Pilkington Committee concludes that the adult educational programmes of the B.B.C. are in themselves very good, but only a start has been made in television. It finds it difficult to see how the growing demand for more television programmes can be met as long as each broadcasting organization has only a one-channel service within which to provide educational programmes as part of a comprehensive service.

The idea of an educational service of broadcasting is discussed in a separate chapter, but is specifically rejected. No specialized service of educational broadcasting, it concludes, should be introduced whether by a new organization or by either of the existing broadcasting authorities. The Committee believes not only that the range of programmes should include educational items, the main purpose of which is specifically to teach, but also that generally educative programmes should have a right of place in all broadcasting. It should also be acknowledged that almost all broadcasting should have an educative effect. The development of a service specializing in education would strike at this concept of education as a purpose of all services of broadcasting, and for this reason the Committee rejected it and reasserted the principle that educational broadcasting in all its 
forms should continue to be the responsibility of the two broadcasting authorities and provided as part of comprehensive services. It recommends that the broadcasting authorities should consult with professional bodies as to the practicability of broadcasting courses of adult education of a vocational nature and that they should try every possibility of improving arrangements for consultation and liaison with the recognized adult educational organizations.

The technical considerations discussed in Chapter 16 are reasonably summarized in the Committee's recommendations on this section. The B.B.C. has so far built twenty-one very-high-frequency sound stations, which serve more than 97 per cent of the population, and, within the frequencies allocated, it is impossible to provide for more high-powered stations, although low-powered relay stations or satellites could be provided, and coverage extended or improved in areas where it is now unsatisfactory. There were no representations that either the B.B.C. or the Independent Television Authority has not executed its plans for expansion as fast as was reasonably possible. The Committee concludes that short-term difficulties and disadvantages of changeover do not outweigh the long-term advantages to be derived from the adoption of the 625-line definition standard recommended by the Television Advisory Committee in its report of May 1960. Accordingly, it recommends that a change in the definition standard in the United Kingdom from 405 to 625 lines be authorized forthwith. A compatible service of colour television should be introduced on this standard, and the further extension of television services should be by broadcast transmission in the V.H.F. Bands IV and $\mathrm{V}$. This decision will involve building very-highfrequency transmitting stations, and the Committee recommends that these transmitting stations of the B.B.C. and the Independent Television Authority should be co-sited and that the Postmaster-General should be given appropriate powers of direction. In allotting the uncommitted frequencies in Band III, it is recommended that first priority should be given to separating the B.B.C.'s service to Wales from that to the English regions, and the second to improving the reception of the two existing programmes and completing their coverage.

\section{CENTRAL ELECTRICITY GENERATING BOARD NEW RESEARCH LABORATORIES}

$\mathrm{A}$ CEREMONY to mark the official opening of the Research Laboratories of the Central Electricity Generating Board at Leatherhead was held on May 10. After an introduction by Sir Christopher Hinton, the laboratories were declared open by the Right Hon. Richard Wood, Minister of Power. Dr. J. S. Forrest, director of the Laboratories, replied. Reference was made by the speakers to the fact that research on a national basis by an electricity authority was initiated in Great Britain in 1930 by the Central Electricity Board. At that time the National Grid was under construction and the need for the experimental investigation of certain problems in high-voltage transmission had been recognized. Small laboratories were established at Croydon and Waddon, and it was of particular interest to note, in connexion with the opening of the new laboratories, that the first member of research staff to be appointed was Dr. J. S. Forrest, the present director.

The Central Electricity Board first set up a laboratory at Leatherhead on a temporary basis in 1940 following damage by enemy air attack at the Waddon laboratories. This site, adjacent to the railway line, at Kingston Road, was afterwards developed, and between 1950 and 1955 had erected on it a number of permanent buildings, including a small high-voltage laboratory. During the same period facilities had been secured on nearby land at Cleeve Road for the erection of a $400-\mathrm{kV}$ experimental high-voltage transmission line. This land adjoined the research laboratories of the Electrical Research Association. It is on a 20-acre site adjacent to the experimental high-voltage line that the new laboratories have been erected (Fig. 1). These comprise a main building with a floor area of about 100,000 square feet, a separate high-voltage laboratory of 35,000 sq. ft., together with a radiographic laboratory, a staff restaurant and recreation building. The buildings at Kingston Road now house the materials division of the laboratories.
The total staff of the laboratories numbers about 750 , of whom roughly one-third are professional engineers or scientists.

The Central Electricity Research Laboratories are organized on the basis of five research divisions described as: High Voltage, Physics, Engineering, Chemistry and Biology, and Materials ; and in addition there are the supporting technical and secretarial services.

The lay-out of the main block of buildings has been arranged architecturally in rather an interesting way. The pond for cooling water and fire fighting has been made a central feature in front of the build. ing and over part, on a sort of isthmus on stilts. stands the lecture theatre. The main block, three storeys high, is backed by two wings each two storeys high, separated by an area at present used as a car park. Behind the west wing is situated the canteen, and in fairly near proximity are a temporary workshop and stores. Some 150 yards away to the north is the high-voltage laboratory and not far from it a small X-ray laboratory.

The ground floor of the main block houses the library, one of the drawing offices, the photography section, together with the typing room, duplicating facilities and administrative offices. The first and second floors are occupied by chemistry, physics. electronics and biology laboratories, the accommodation comprising for the most part rooms ranging in size from 200 to 1,250 sq. ft.

The design of the two wings was influenced by experience gained in earlier laboratories. This had demonstrated the necessity of providing fairly large areas of floor space on ground-level on which heavy experimental plant could be erected. Large-scale 'test rigs' require access to the major engineering services, suitable arrangements of foundations. head room, crane facilities and access and transport facilities. Indeed, the provisions required are similar to those of the 'test bed' of a manufacturer of machinery or electrical plant. One such area is provided 